\title{
INTERNAL MEDICINE
}

\section{Volume 49 Number 3 February 2010}

\section{CONTENTS}

\section{CASE REPORT}

Gastrointestinal Diseases

Patient with Eight Metachronous Gastrointestinal Cancers Thought to be Hereditary

Nonpolyposis Colorectal Cancer (HNPCC)

Yamasaki Y, Matsushima M, Tanaka H, Tajiri S, Fukuda R, Ozawa H, Takagi A, Hirabayashi K and Sadahiro $S$

Cardiovascular Diseases

Successful Percutaneous Revascularization in a Patient with a Chronic Totally Occluded

Renal Artery in an Atrophied Kidney Nagata Y, Taniguchi $Y$, Usuda $K$, Kawabata $M$ and Iida $H$

Left-sided ICD Implantation via Right-sided Venous Access in a Patient with Left Hemodialysis

Fistula

Saito A, Kaneko Y, Nakajima T, Irie T, Ota M, Kato T, Iijima T, Akiyama M, Ito T, Manita M and

Kurabayashi M

Endocrine-Metabolic Diseases

The Ratio of the Blood Urea Nitrogen/Creatinine Index in Patients with Acute Renal Failure is

Decreased due to Dextran or Mannitol

Kouki T, Komiya I and Masuzaki $\mathrm{H}$

Hematological Diseases

Plasma Cell Granuloma of the Sigmoid Colon Associated with Diverticular Disease and

Accompanying IgM-Type Monoclonal Gammopathy

Nakamura Y, Kayano H, Shimada T, Ito Y and Bessho M

Endoscopic Follow-up of $\mathbf{3}$ Cases with Gastrointestinal Tract Involvement of Mantle Cell

Lymphoma

Saito M, Mori A, Irie T, Tanaka M, Morioka M, Ozasa M, Kobayashi T, Saga A, Miwa K and Tanaka S

Neurologic Diseases

Successful Treatment with Rituximab in a Patient with Stiff-Person Syndrome Complicated by

Dysthyroid Ophthalmopathy Katoh N, Matsuda M, Ishii W, Morita $\mathrm{H}$ and Ikeda $\mathrm{S}$

Conventional Diet Therapy for Hyperammonemia is Risky in the Treatment of Hepatic

Encephalopathy Associated with Citrin Deficiency

Fukushima K, Yazaki M, Nakamura M, Tanaka N, Kobayashi K, Saheki T, Takei H and Ikeda S

\section{PICTURES IN CLINICAL MEDICINE}

\section{Endocrine-Metabolic Diseases}

Craniofacial Fibrous Dysplasia

Pruksakorn P, Shuangshoti S, Siwanuwatn R, Lerdlum S, Sunthornyothin S and Snabboon T

Internal Medicineは，本会が発行するOnline Journalです.

下記サイトで，投稿ならびに閲覧ができます.

http://www.naika.or.jp/imonline/index.html 


\section{次号予告 (第 3 号)}

特集 : 第37回内科学の展望

「動脈硬化症発症・進展阻止に向けて」

一生活習慣病予防から心血管再生医療まで一

\section{1. 序論}

2.メタボリックシンドロームとインスリン抵抗 性

3. 動脈硬化症の 1 次予防
1) 高血圧
2) 糖尿病
3）脂質異常症
4）心腎連関の立場から

4. 心血管系疾患治療の最前線
1）脳卒中
2）虚血性心疾患
3）重症不整脈と心不全～心不全例の予後改善 を目指して〜
4）血管再生療法の展望

5. まとめ
平成 21 年度日本内科学会生涯教育講演会

Aセッション

消化器, 内分泌・代謝, 神経, アレルギー・ 膠原病, 内科一般・腫瘍

$\mathrm{B}$ セッション

循環器, 腎臓, 呼吸器, 血液, 感染症, 内科 診療
- 会 頭

- 理事長

- 編集担当理事 片山 茂裕, 松尾 清一

・編集主任浅香 正博

- 編集副主任岡本 幸市, 檀 和夫

・編集委員

小林 祥泰

寺本 民生
石橋 大海, 伊藤 光泰, 犬塚

久保 惠嗣, 小池

和彦, 澤田

貴, 今井 裕一, 江口

研二, 北村 和雄

中川 正法, 永井

厚志, 中原

賢一, 下瀬川 徹, 田中

良哉, 土井

俊夫

福井 次矢, 藤山

佳秀, 山本

一彦, 渡辺彰

\section{日本内科学会雑誌 第99巻 臨時増刊号}

平成 22 年 2 月 16 日印刷・平成 22 年 2 月 20 日発行

会員外頒価一部 1,000 円（税込）

\section{編集人 編集主任 浅香 正博 \\ 発行所 社団法人 日本内科学会 \\ 干113-8433 東京都文京区本郷 3 丁目28番 8 号 \\ 電話（03) 3813-5991(代) FAX（03) 3818-1556 \\ E-mailnaika@naika.or.jp http://www.naika.or.jp \\ 印刷所 ₹114-0024 東京都北区西ヶ原 3 丁目46番10号 株式会社 杏 林 舎}

\footnotetext{
複写される方へ：本会は下記協会に複写に関する権利委託をしていますので，本誌に掲載された著作物を複写したい方は，同協会より 許諾を受けて複写して下さい. 但し (社) 日本複写権センター (同協会より権利を再委託) と包括複写許諾契約を締結されている企業 の社員による社内利用目的の複写はその必要はありません。（社外頒布用の複写は許諾が必要です.）

権利委託先：(中法) 学術著作権協会 T107-0052 東京都港区赤坂9-6-41 乃木坂ビル

電話（03)3475-5618 FAX (03)3475-5619 E-mail:info@jaacc.jp

なお, 著作物の転載・翻訳のような, 複写以外の許諾は, 学術著作権協会では扱っていませんので, 直接発行団体へご連絡ください.

また, アメリカ合衆国において本書を複写したい場合は, 次の団体に連絡して下さい.

Copyright Clearance Center, Inc. 222 Rosewood Drive, Danvers, MA 01923 USA, Phone 1-978-750-8400 FAX 1-978-646-8600
} 